\title{
Meat production of young and adult Kejobong goats fed diets with different protein concentration
}

\author{
Nuning Ari Purnami*, Endang Purbowati dan Edy Rianto \\ Faculty of Animal and Agricultural Sciences \\ Universitas Diponegoro, Semarang, 50275, Indonesia
}

Submitted: 17 April 2020, Accepted: 25 March 2021

\begin{abstract}
This study was aimed to examine the effect of dietary crude protein $(\mathrm{CP})$ concentration on carcass and meat production in young and adult Kejobong goats. This study used 8 young ( 5 months) and 8 adult ( 9 months) Kejobong goats; which were allocated to a randomized nested design, with an age of goat as the nest, and treatment applied was dietary protein concentration (T1: 9.96\%; T2: 14.66\%). The parameters observed were dry matter intake (DMI), CP intake (CPI), body weight gain (BWG), and the production of carcass meat. The results showed that the DMI of adult goats $(910 \mathrm{~g} / \mathrm{d})$ was higher $(\mathrm{P}<0.05)$ than that of young goats $(680 \mathrm{~g} / \mathrm{d})$. The goats fed diet $\mathrm{T} 2$ had higher $(\mathrm{P}<0.05)$ DMI, CPI, and BWG $(855$ $\mathrm{g}, 140 \mathrm{~g}$, and $94 \mathrm{~g} / \mathrm{d}$, respectively) than those of T1 $(725 \mathrm{~g} / \mathrm{d}, 80 \mathrm{~g} / \mathrm{d}$, and $59 \mathrm{~g} / \mathrm{d})$. Slaughter weight, carcass weight and carcass meat weight, and carcass meat percentage of adult goats $(28.09 \mathrm{~kg}, 13.19 \mathrm{~kg}, 8.60 \mathrm{~kg}$ and $64.94 \%$, respectively) were higher $(\mathrm{P}<0.05)$ than those of young goats $(20.06 \mathrm{~kg}, 8.72 \mathrm{~kg}, 5.46 \mathrm{~kg}$, and $62.06 \%$, respectively). The weight and percentage of carcass meat of T2 $(8.30 \mathrm{~kg}$ and $64.99 \%$, respectively $)$ were higher $(\mathrm{P}<0.05)$ than those of $\mathrm{T} 1(5.75 \mathrm{~kg}$ and $62.06 \%$, respectively). The meat-bone ratio of adult goats was higher $(\mathrm{P}<0.05)$ than that of young goats ( 3.53 vs 2.85$)$. The meat-bone ratio of $\mathrm{T} 2(3.58)$ was higher $(\mathrm{P}<0.05)$ than that of T1 (2.80). It was concluded that adult Kejobong goats produced more meat than the young ones, and the goat-fed diet with $14.66 \% \mathrm{CP}$ produced more meat than that with $9.96 \% \mathrm{CP}$.
\end{abstract}

Keywords: Kejobong goats; Meat production; Dietary protein

*Corresponding Author: nuningarii@gmail.com 


\section{INTRODUCTION}

Kejobong goat is a local type of meat goat that can play a role in meeting the needs of animal protein in Indonesia (Socheh et al., 2011). Generally, Kejobong goats in smallscale farms are only given forage. The low nutrition contained in forage results in a low production level. A one-year-old Kejobong goat with a bodyweight of $23.45 \mathrm{~kg}$ has a carcass percentage of $44.69 \%$, with $62.33 \%$ meat, $26.01 \%$ bone, $9.5 \%$ fat, and $2.28 \%$ connective tissue (Sumardianto et al., 2013).

An increase in feed nutrition is needed to increase the production of carcass components. Increasing nutrition can be done by increasing the concentrations of dietary protein. Dietary protein consumed by the animal is used for the deposition of body tissues (Atti et al., 2004). The increase in dietary protein content will increase the deposition of body tissues, so that carcass meat production can increase. The meat production is influenced by carcass weight. The results of research by Dutta et al. (2009) on the Barbari goat showed that giving 14\% dietary protein was able to produce a higher carcass weight than giving $12 \%$ dietary protein. Choi et al. (2005) reported that Korean goats fed diet containing 14\% protein produced a final weight $(25.28 \mathrm{~kg})$ higher than that fed diet with protein content of 12 and $16 \%$, namely 23.66 and $24.54 \mathrm{~kg}$. On the other hand, a high body weight gain tends to increase fat deposition. Several studies have shown that feeding a highquality diet during the fattening period increased body weight gain and body fat content in cattle (Meyer et al., 2005), goats (Atti et al., 2004), and sheep (Yalcintan et al., 2017).

The animal production level is also influenced by the age of the animal. According to Owens et al. (1993), the growth rate based on age starts with bone growth, followed by meat and then fat. Mushi et al. (2009) stated that goat meat production is influenced by age and feed. Adult goats have optimal bone growth followed by high meat growth, but adult goats are also in an accelerated fatdeposition phase. To obtain high meat production with low-fat content, fattening young goats can be a solution. Young goats are still in the phase of accelerated bone and muscle growth, and fat deposition is still slow.

Research on the production of Kejobong goat meat which is raised intensively with different ages and dietary protein content has never been carried out, so it is necessary to do research. The purpose of this study was to examine the effect of age and dietary protein concentrations on the meat production of Kejobong goats.

\section{MATERIALS AND METHODS}

The materials used in this study were 16 male Kejobong goats, consisting of 8 adult goats (9 months old) with an average body weight of $22.32 \pm 1.99 \mathrm{~kg}(\mathrm{CV}=$ $8.92 \%$ ) and 8 heads young goats (age 5 months) with an average weight of $14.03 \pm$ $1.46 \mathrm{~kg}(\mathrm{CV}=10.43 \%)$. The feed was given in the form of pellets consisting of Kolonjono grass (Panicum muticum) and concentrate. The concentrate composition consists of $6 \%$ cassava flour by-product, $45 \%$ soybean meal, $42 \%$ bran, $6 \%$ molasses, and $1 \%$ mineral mix. The design used was nested as recommended by Kaps and Lamberson (2009), with age (young and adult) of goats as the nest factors, and the ratio of forage and concentrate as the feed treatment $(\mathrm{T} 1=70 \%$ grass and $30 \%$ concentrate; $\mathrm{T} 2=30 \%$ grass and $70 \%$ concentrate). The composition and nutritional content of the experimental diets in this study are presented in Table 1.

The experimental goats were reared for 15 weeks with feeding based on dry matter (DM) needs as much as $4 \%$ of body weight. The diet offered and the refusals were weighed to determine daily intake. Goats were weighed every week to determine body weight and adjust the amount of feed they were given. The goats were slaughtered in week 16 . The process of slaughtering began with fasting the goat for 
12 hours. After slaughtering, the head occipito-atlantois joint, tail, front legs, and rear legs were cut, and the viscera was removed. The carcass obtained was then weighed and withered according to the recommendation of Soeparno (2015).
Furthermore, the carcass was weighed to obtain cold carcass weight. After that, the carcass was separated from the kidneys and pelvic fat. Carcass was weighed without kidney and pelvic fat. After that, the carcass was cut into two parts, right and left sides.

Table 1. Composition and Nutrient Content of the Experimental Diets

\begin{tabular}{lcc}
\hline \multirow{2}{*}{ Feedstuff } & \multicolumn{2}{c}{ Treatment } \\
\cline { 2 - 3 } & T1 & T2 \\
\cline { 2 - 3 } Kolonjono Grass (Panicum muticum) & 70 & 30 \\
Concentrate & 30 & 70 \\
Nutrient content of the Experimental Diets & & \\
Ash & 12.29 & 14.77 \\
Crude Protein & 9.96 & 14.66 \\
Ether Extract & 0.45 & 0.74 \\
Crude Fiber & 24.97 & 21.51 \\
Nitrogen Free Extract & 52.33 & 48.30 \\
Total Digestible Nutrients & 73.77 & 72.81 \\
\hline
\end{tabular}

The right carcass was cut into 8 commercial pieces, namely neck, shoulder, rack, loin, leg, flank, breast, and foreshank. Each commercial cut was broken down based on meat, bone, intermuscular fat, subcutaneous fat, and connective tissue. Every part of was weighed.

The parameters observed were DM intake (DMI), dietary protein intake (DPI), body weight gain (BWG), slaughter weight, carcass weight and percentage, weight and percentage of carcass components, and meat-bone ratio. The DMI was calculated from the difference between the DM offered and the DM refusals, then DMI and DPI were calculated. The BWG was calculated based on initial body weight, final body weight, and length of observation. Slaughter weight and carcass weight were known from the weighing results. The weight of the carcass components was known from the weight of each carcass component after dissection, including meat, bone, and subcutaneous fat, intermuscular fat, and connective tissue. The percentage of carcass components was the percentage weight of the carcass components to the carcass weight. Meat-bone ratio and the ratio between carcass meat weight and carcass bone weight.

Dry Matter Intake $(\mathrm{g})=$ Feed Intake $(\mathrm{g}) \times \%$ Dietary Dry Matter Content

Dietary Protein intake $(\mathrm{g})=$ Dry Matter Intake $(\mathrm{g}) \times \%$ Dietary Protein Content Body Weight Gain (g/day) = Final Body Weight - Initial Body Weight (g)/Length of maintenance (day)

$$
\begin{gathered}
\text { Percentage of Carcass Component }(\%)=\frac{\text { Carcass Component Weight }(\mathrm{kg})}{\text { Carcass Weight }(\mathrm{kg})} \times 100 \% \\
\text { Meat-Bone Ratio }=\frac{\text { Carcass Meat Weight }(\mathrm{kg})}{\text { Carcass Bone Weight }(\mathrm{kg})}
\end{gathered}
$$


The data obtained were analyzed using ANOVA (Analysis of Variance) of nested design according to Kaps and Lamberson (2009). The calculated F value obtained is compared with the $\mathrm{F}$ table value of $5 \%$ level. A P-value $\leq 0.05$ was considered as significant.

\section{RESULT AND DISCUSSION Dry Matter Intake and Body Weight Gain}

The results of the study showed that the DMI and DPI of adult goats were higher $(\mathrm{P}<0.05)$ than those of young goats (Table $2)$. This was presumably because the volume of the digestive tract, especially the rumen of the adult goat was bigger than that of the young goat, so the adult goat could accommodate a greater amount of feed. Lawrence et al. (2012) stated that feed intake is influenced by the volume of the digestive organs of the animal; the larger the size of the digestive tract, the higher the feed capacity. The BWG of young and adult Kejobong goats was not significantly different $(\mathrm{P}>0.05)$, with an average of 78 $\mathrm{g} /$ day. The young goat (aged 5 months) was in the accelerated growth phase, while the growth rate of the adult goat (aged 9 months) was slowing down, so that the resulted body weight gain was similar. According to Webb (2014) and Brand et al. (2017) the animal growth rate is influenced by its age. In an animal that has not reached the peak of growth, the nutrient is used for growth and tissue development, then when it reaches the peak of growth, most of the nutrient is used for production. Meanwhile, an adult goat has a high body weight, so that the nutritional requirements for basic metabolism is also high, and so that smaller amount of nutrient is available for meat production.

Table 2. Feed Intake and Body Weight Gain of Kejobong Goats

\begin{tabular}{lllll}
\hline \multicolumn{1}{c}{ Feed Intake and BWG } & Age & T1 & T2 & Average \\
\hline \multirow{2}{*}{ Dry Matter Intake (g) } & Young & $583^{\mathrm{a}}$ & $767^{\mathrm{b}}$ & $675^{\mathrm{x}}$ \\
\hline \multirow{2}{*}{ Dietary Protein Intake (g) } & Adult & $872^{\mathrm{a}}$ & $944^{\mathrm{b}}$ & $908^{\mathrm{y}}$ \\
\hline \multirow{2}{*}{ Body Weight Gain (g/day) } & Young & $58^{\mathrm{a}}$ & $112^{\mathrm{b}}$ & $85^{\mathrm{x}}$ \\
& Adult & $87^{\mathrm{a}}$ & $138^{\mathrm{b}}$ & $112^{\mathrm{y}}$ \\
\hline
\end{tabular}

Notes: ${ }^{\mathrm{a}, \mathrm{b}}$ Different superscripts on the same row show significant differences between feed treatments $(\mathrm{P}<0.05)$.

${ }^{\mathrm{x}, \mathrm{y}}$ Different superscripts in the same column show significantly different between ages $(\mathrm{P}<0.05)$.

The goat given the diet of higher protein concentration (T2) had higher DMI, DPI, and BWG $(\mathrm{P}<0.05)$ than those given lower protein concentration (T1), both in young and adult goats.

The increase in dietary protein content caused an increase in DMI and BWG. Atti et al. (2004), Mushi et al. (2009), Dutta et al. (2009), and Choi et al. (2005) stated that increasing dietary protein content resulted in an increased BWG of goats. Another factor that plays a role in DMI was the fact that the CF content in $\mathrm{T} 1(24.97 \%)$ was higher than that of $\mathrm{T} 2(21.51 \%)$. This caused the digestibility of the diet $\mathrm{T} 1$ to be low and in turn slows down the rate of digestion in the digestive tract, and ultimately resulted in low DMI. The low DMI in turn caused BWG in goat T1 to be lower than that of goat T2. Poppi et al. (1994) and Sayekti et al. (2015) stated that DMI is influenced by the rate of digestion, the faster the digestion rate, the higher the DMI that resulting in a higher growth rate.

\section{Slaughter Weight, Carcass Weight, and Carcass Percentage}

The weight and carcass percentage of the young goat were lower $(\mathrm{P}<0.05)$ than the adult goat. This was because the slaughter weight of the young goat was also lower $(\mathrm{P}<0.05)$ than that of the adult goat. Mushi et al. (2009) stated that the factors 
influencing the percentage and carcass weight are breed, sex, age, and nutrition. The initial bodyweight of the young goat was lower, resulting in lower slaughter weight, as compared to that of the adult goat. This is in line with the results of several other research showing that slaughter weight affects carcass weight and percentage; the higher the body weight, the higher the carcass weight and percentage (Polidori et al., 2017; Zhang et al., 2020). This occurs because, in the process of increasing body weight, most of the deposition of nutrients occurs in the carcass component tissue, while in the non-carcass component tissue deposition occurs less. Slaughter weight, carcass weight, and carcass percentage of goats receiving $\mathrm{T} 2$ rations were higher $(\mathrm{P}$ $<0.05)$ than $\mathrm{T} 1$, both for young and adult goats. T2 goats consume more feed than T1 goats, so that $\mathrm{T} 2$ goats have a higher body weight gain rate than $\mathrm{T} 1$ goats (Table 2), and in the end, the slaughter weight of $\mathrm{T} 2$ goats is higher than $\mathrm{T} 1$ goats.

Table 3. Slaughter Weight, Cascass Weight, and Carcass Percentage

\begin{tabular}{|c|c|c|c|c|}
\hline & Age & $\mathrm{T} 1$ & $\mathrm{~T} 2$ & Average \\
\hline \multirow{3}{*}{ Slaughter Weight } & Young & $16.98^{\mathrm{a}}$ & $23.13^{b}$ & $20.06^{x}$ \\
\hline & Adult & $25.51^{\mathrm{a}}$ & $30.67^{\mathrm{b}}$ & $28.09^{y}$ \\
\hline & Average & 21.25 & 26.90 & \\
\hline \multirow{3}{*}{ Carcass Weight } & Young & $6.74^{\mathrm{a}}$ & $10.80^{\mathrm{b}}$ & $8.72^{\mathrm{x}}$ \\
\hline & Adult & $11.73^{\mathrm{a}}$ & $14.65^{\mathrm{b}}$ & $13.19^{y}$ \\
\hline & Average & 9.24 & 12.73 & \\
\hline \multirow{3}{*}{ Carcass Percentage } & Young & $43.11^{\mathrm{a}}$ & $49.71^{b}$ & $46.41^{x}$ \\
\hline & Adult & $48.31^{\mathrm{a}}$ & $51.15^{\mathrm{b}}$ & $49.73^{\mathrm{y}}$ \\
\hline & Average & 45.70 & 50.43 & \\
\hline Notes: & ripts on the & $\begin{array}{l}\text { w show } \\
\text { w show }\end{array}$ & $\begin{array}{l}\text { th differe } \\
\text { th differe }\end{array}$ & $\begin{array}{l}\text { n feed treatments }(P \\
\text { n feed treatments }(P\end{array}$ \\
\hline
\end{tabular}

\section{Production of Carcass Components}

Data on the weight and percentage of components (meat, bone, subcutaneous fat, intermuscular fat, and connective tissue) of carcass and meat-bone ratio can be seen in Table 4. The weight of meat, bone, subcutaneous fat, intermuscular fat, and connective tissue of young goats is lower $(\mathrm{P}$ $<0.05$ ) than adult goats, but bone weight was not significantly different $(\mathrm{P}>0.05)$ between young and adult goats. Young goats had a lower percentage of meat $(\mathrm{P}<0.05)$ and higher bone $(\mathrm{P}<0.05)$ than adult goats, while the percentage of subcutaneous fat, intermuscular fat, and connective tissue at the two goat ages was not significantly different $(P>0.05)$. In the process of growth, bones have the slowest growth rate. This is indicated by the lower percentage of bone in adults than at young age. Meanwhile, the meat component has the fastest growth rate, so that at adulthood the percentage is higher than at a young age.

Connective tissue weight increases with increasing body weight, so that the percentage is not significantly different $(\mathrm{P}>0.05)$ between young and adult goats. Among other things, connective tissue functions to wrap muscles so that they do not rub against other muscles. The bigger the muscle, the bigger the connective tissue that wraps it. According to Marichal et al. (2003), Mushi et al. (2009), and Jiyanto (2014) stated that the weight of the carcass components corresponds to the weight of cattle when slaughtered. The proportion of subcutaneous and intermuscular fat in young goats and adult goats was not significantly different $(\mathrm{P}>0.05)$. This shows that the adult goats in this study have not yet entered the 
intensive fat deposition phase, which is the phase where body weight gain is dominated by fat weight gain.

This is in line with the results of research by Rajkumar et al. (2010) also showed that Sirohi goats until the age of 12 months had not yet experienced intensive accumulation of fat. According to Lawrence et al. (2012) and Soeparno (2015), the development of livestock tissue starts from the nervous system, bones, tendons, muscles, intermuscular fat than subcutaneous fat. The meat-bone ratio in young goats is lower than adult goats. This is because young goats have a higher percentage of bone and a lower percentage of meat and fat than adult goats. In the growth process, bone is the body tissue that ripens early, followed by muscle and fat (Lawrence et al. 2012; Soeparno, 2015).

Table 4. Weight dan Percentage of Carcass Component

\begin{tabular}{|c|c|c|c|c|c|c|c|}
\hline \multirow{2}{*}{ Carcass Component } & \multirow{2}{*}{ Age } & \multicolumn{3}{|c|}{ Weight (g) } & \multicolumn{3}{|c|}{ Percentage (\%) } \\
\hline & & $\mathrm{T} 1$ & $\mathrm{~T} 2$ & Average & $\mathrm{T} 1$ & $\mathrm{~T} 2$ & Average \\
\hline \multirow{3}{*}{ Meat } & Young & $4.021^{\mathrm{a}}$ & $6.895^{\mathrm{b}}$ & $5.458^{x}$ & $60.38^{c}$ & $63.75^{\mathrm{d}}$ & $62.06^{x}$ \\
\hline & Adult & $7.481^{\mathrm{a}}$ & $9.709^{b}$ & $8.595^{\mathrm{y}}$ & $63.74^{\mathrm{c}}$ & $66.23^{\mathrm{d}}$ & $64.94^{y}$ \\
\hline & Average & $5.751^{\mathrm{a}}$ & $8.302^{\mathrm{b}}$ & & $62.06^{\mathrm{c}}$ & $64.99^{\mathrm{d}}$ & \\
\hline \multirow{3}{*}{ Bone } & Young & 1.710 & 2.070 & $1.890^{\mathrm{x}}$ & 24.66 & 19.15 & $21.91^{x}$ \\
\hline & Adult & 2.360 & 2.542 & $2.451^{\mathrm{y}}$ & 20.09 & 17.36 & $18.73^{y}$ \\
\hline & Average & 2.035 & 2.306 & & $22.38^{c}$ & $18.26^{\mathrm{d}}$ & \\
\hline \multirow{3}{*}{ Subcutan fat } & Young & $304^{\mathrm{a}}$ & $622^{\mathrm{b}}$ & $463^{x}$ & 4.75 & 5.90 & 5.32 \\
\hline & Adult & $614^{\mathrm{a}}$ & $901^{\mathrm{b}}$ & $758^{y}$ & 5.27 & 6.19 & 5.73 \\
\hline & Average & $459^{\mathrm{a}}$ & $762^{\mathrm{b}}$ & & 5.01 & 6.04 & \\
\hline \multirow{3}{*}{ Intramuscular fat } & Young & $287^{\mathrm{a}}$ & $620^{\mathrm{b}}$ & $453^{x}$ & 4.16 & 5.71 & 4.94 \\
\hline & Adult & $590^{\mathrm{a}}$ & $707^{b}$ & $648^{y}$ & 4.96 & 4.81 & 4.88 \\
\hline & Average & $438^{\mathrm{a}}$ & $664^{\mathrm{b}}$ & & 4.56 & 5.26 & \\
\hline \multirow{3}{*}{ Connective tissue } & Young & $402^{\mathrm{a}}$ & $596^{\mathrm{b}}$ & $499^{x}$ & 6.05 & 5.49 & 5.77 \\
\hline & Adult & $690^{\mathrm{a}}$ & $793^{b}$ & $742^{y}$ & 5.94 & 5.41 & 5.68 \\
\hline & Average & $546^{\mathrm{a}}$ & $694^{\mathrm{b}}$ & & 5.99 & 5.45 & \\
\hline \multirow{3}{*}{ Meat-Bone Ratio } & Young & $2.37^{\mathrm{a}}$ & $3.33^{b}$ & $2.85^{\mathrm{x}}$ & & & \\
\hline & Adult & $3.23^{\mathrm{a}}$ & $3.82^{\mathrm{b}}$ & $3.53^{\mathrm{y}}$ & & & \\
\hline & Average & $2.80^{\mathrm{a}}$ & $3.58^{\mathrm{b}}$ & & & & \\
\hline
\end{tabular}

Notes: ${ }^{\mathrm{a}, \mathrm{b}}$ Different superscripts on the same row showed significant differences between feed treatments on carcass component weight and meat-bone ratio $(\mathrm{P}<0.05)$.

${ }^{c, d}$ Different superscripts on the same row showed significant differences between feed treatments on the percentage of carcass components $(\mathrm{P}<0.05)$.

${ }^{\mathrm{x}, \mathrm{y}}$ Different superscripts in the same column showed significant differences between ages $(\mathrm{P}<0.05)$.

Goats fed T2 had higher meat weight, subcutaneous fat weight, intermuscular fat weight, and connective tissue weight ( $\mathrm{P}$ $<0.05)$ compared to goats fed $\mathrm{T} 1$, both young and adult goats. Meanwhile, bone weight was not significantly different $(\mathrm{P})$ 0.05 ) between treatments. The higher protein content in the $\mathrm{T} 2$ feed resulted in more protein deposited for tissue growth. Besides, the consumption of BK in T2 goats is also higher than T1 goats, both in young and adult goats, so that the nutrients deposited in the body tissue of $\mathrm{T} 2$ goats are more than in $\mathrm{T} 1$ goats. This is in line with the opinion of Mushi et al. (2009) and Dutta et al. (2009) stated that an increase in feed protein content will increase the deposition of livestock body tissue.

The absence of a significant effect of feed treatment on bone weight indicated that the bone growth rate was not only affected by DMI or DPI, but several other factors were more dominant. The research results of Elfers et al. (2016) showed that an increase in protein content without the addition of calcium content in the ration did not affect bone growth in young goats. The percentage of goat bones with $\mathrm{T} 2$ feed was lower $(\mathrm{P}$ 
$<0.05)$ than $\mathrm{T} 1$. This occurred because the weight of meat, fat and connective tissue of T2 were higher, so the proportion of bone to carcass was low. This was in line with the opinion of Soeparno (2015) that differences in the weight of a component of the animal carcass will affect the percentage of other carcass components.

\section{CONCLUSIONS}

This study concludes that increasing the protein concentration from $9.96 \%$ to $14.66 \%$ in the diet increases the rate of body weight gain, carcass production, and meat production of Kejobong goat, both young and adult. The increase in production rate is followed by the deposition of body fat. Based on the results of this study suggested goat fattening Kejobong at 5 months of age can be done by feeding $14.66 \% \mathrm{CP}$ concentration.

\section{REFERENCES}

Atti, N., Rouissi, H., \& Mahouachi, M. (2004). The effect of dietary crude protein level on growth, carcass and meat composition of male goat kids in Tunisia. Small Ruminant Research, 54(1-2), 89-97. https://doi.org/10.10 16/j.smallrumres.2003.09.010

Brand, T. S., Van Der Merwe, D. A., Hoffman, L. C., \& Geldenhuys, G. (2018). The effect of dietary energy content on quality characteristics of Boer goat meat. Meat Science, 139, 74-81. https://doi.org/10.1016/j.meat sci.2018.01.018

Choi, S. H., Kim, S. W., Park, B. Y., Sang, B. D., Kim, Y. K., Myung, J. H., \& Hur, S. N. (2005). Effects of dietary crude protein level on growth and meat quality of Korean native goats. Journal of Animal Science and Technology, 47(5), 783-788. https:// doi.org/10.5187/JAST.2005.47.5.783

Dutta, T. K., Agnihotri, M. K., Sahoo, P. K., Rajkumar, V., \& Das, A. K. (2009). Effect of different protein-energy ratio in pulse by-products and residue based pelleted feeds on growth, rumen fermentation, carcass and sausage quality in Barbari kids. Small Ruminant Research, 85(1), 34-41. https://doi.org/10.1016/j.smallrumres. 2009.07.002

Elfers, K., Liesegang, A., Wilkens, M. R., Breves, G., \& Muscher-Banse, A. S. (2016). Dietary nitrogen and calcium modulate bone metabolism in young goats. The Journal of Steroid Biochemistry and Molecular Biology, 164, 188-193. https://doi.org/10.1016 /j.jsbmb.2015.11.007

Jiyanto, J., Sutopo, S., \& Kurnianto, E. (2014). The genetic diversity of kejobong goat based on cytochrome B gene. Journal of the Indonesian Tropical Animal Agriculture, 39(2), 75-82. https://doi.org/10.14710/jitaa. 39.2.75-82

Kaps, M., \& Lamberson, W. R. (2009). Biostatistic for Animal Science, an Introductory Text (2nd ed.). CABI Wallingford.

Lawrence, T. L. J., Fowler, V. R., \& Novakofksi, J. E. (2012). Growth of Farm Animal (2nd ed.). CABI Wallingford.

Marichal, A., Castro, N., Capote, J., Zamorano, M. J., \& Argüello, A. (2003). Effects of live weight at slaughter $(6,10$ and $25 \mathrm{~kg})$ on kid carcass and meat quality. Livestock Production Science, 83(2-3), 247256. https://doi.org/10.1016/S0301-6 226(03)00113-1

Meyer, D. L., Kerley, M. S., Walker, E. L., Keisler, D. H., Pierce, V. L., Schmidt, T. B., Stahl, C. A., Linville, M. L., \& Berg, E. P. (2005). Growth rate, body composition, and meat tenderness in early vs. traditionally weaned beef calves1,2. Journal of Animal Science, 83(12), 2752-2761. https://doi.org/10. 2527/2005.83122752x

Mushi, D. E., Eik, L. O., Thomassen, M. S., Sørheim, O., \& Ådnøy, T. (2008). Suitability of Norwegian short-tail lambs, Norwegian dairy goats and Cashmere goats for meat production - 
Carcass, meat, chemical and sensory characteristics. Meat Science, 80(3), 842-850. https://doi.org/10.1016/j.me atsci.2008.03.032

Owens, F. N., Dubeski, P., \& Hanson, C. F. (1993). Factors that alter the growth and development of ruminants. Journal of Animal Science, 71(11), 3138-3150. https://doi.org/10.2527/ 1993.71113138x

Polidori, P., Pucciarelli, S., Cammertoni, N., Polzonetti, V., \& Vincenzetti, S. (2017). The effects of slaughter age on carcass and meat quality of Fabrianese lambs. Small Ruminant Research, 155, 12-15. https://doi.org/10.1016/ j.smallrumres.2017.08.012

Poppi, D. P., Gill, M., \& France, J. (1994). Integration of theories of intake regulation in growing ruminants. Journal of Theoretical Biology, 167(2), 129-145. https://doi.org/10. 1006/jtbi.1994.1058

Rajkumar, V., Agnihotri, M. K., Das, A. K., Ramachandran, N., \& Singh, D. (2010). Effect of age on carcass characteristics and meat quality of Sirohi goat kids reared under semiintensive and intensive management systems. Indian Journal of Animal Sciences, 80(8), 775-780.

Sayekti, I., Purbowati, E., \& Rianto, E. (2015). Dietary protein utilization in local rams given feed during the day and night. Animal Agriculture, 4(1), 22-27.

Socheh, M., Ismaya, I., S. Budisatria, I. G.,
\& Kustantinah, K. (2017). Pengaruh flushing berbasis pakan lokal terhadap pertumbuhan dan birahi kambing kejobong betina dewasa. Sains Peternakan, 9(2), 53-64. https://doi. org/10.20961/sainspet.v9i2.4784

Soeparno. (2015). Ilmu dan Teknologi Daging. Universitas Gadjah Mada Press.

Sumardianto, T. A. P., Purbowati, E., \& Masykuri. (2013). Karakteristik karkas kambing kacang, kambing peranakan ettawa, dan kambing kejobong jantan pada umur satu tahun. Journal, Animal Agriculture, 2(1), 175-182.

Webb, E. C. (2014). Goat meat production, composition, and quality. Animal Frontiers, 4(4), 33-37. https://doi.org/ 10.2527/af.2014-0031

Yalcintan, H., Ekiz, B., Kocak, O., Dogan, N., Akin, P. D., \& Yilmaz, A. (2017). Carcass and meat quality characteristics of lambs reared in different seasons. Archives Animal Breeding, 60(3), 225-233. https://doi. org/10.5194/aab-60-225-2017

Zhang, N., Teng, Z., Qi, Q., Hu, G., Lian, H., \& Gao, T. (2020). Carcass traits, meat quality characteristics, and lipid metabolism-related gene expression pattern of Yaoshan white goats raised in traditional extensive production system: Effects of slaughter age and meat cuts. Small Ruminant Research, 182, 29-36. https://doi.org/10.1016/ j.smallrumres.2019.11.004 